\title{
Physiological and Biochemical Responses in Onion Crop to Drought Stress
}

\author{
P.H. Ghodke*, P.S. Andhale, U.M. Gijare, A. Thangasamy, \\ Y.P. Khade, V. Mahajan and M. Singh \\ (Plant Physiology) ICAR-Directorate of Onion and Garlic Research, \\ Rajgurunagar, Pune, India \\ *Corresponding author
}

\section{Keywords \\ Onion, Drought, Physiological, \\ Biochemical, \\ Growth and yield}

Article Info

Accepted:

14 December 2017

Available Online:

10 January 2018

\section{A B S T R A C T}

Drought is one of the major abiotic constraints limiting onion world-wide. To address the issue, study was conducted to investigate the effect of drought on morpho-physiological and biochemical parameters in onion variety Bhima Kiran in Rabi 2016. Drought stress was imposed on well-established seedlings by with-holding irrigation for continuous 40 days. The soil moisture and plant water status decreased gradually as the drought stress progresses beyond 30 days. Result showed that drought stress significantly reduces the leaf length and leaf area without any significant variation for other morphological traits namely, leaves per plant, height, pseudo-stem length and diameter. The onion variety Bhima Kiran maintains chlorophyll content confirming its functional stay-green property and accumulate higher proline, total soluble solids and antioxidant enzyme activity in response to drought as one of the tolerance mechanism. Water deficit stress lead to $65 \%$ yield reduction with more $\mathrm{C}$ grade bulbs $(<30 \mathrm{~mm})$. Additionally, slightly decreases in quality parameters like protein, phenol, flavanoids and pyruvic acid in bulbs were observed subjected to drought. Hence, the popular Rabi onion variety Bhima Kiran respond to drought stress by altering it biochemical pathway and thereby maintain its survival under stress. This finding briefly highlights the drought tolerance mechanisms in Bhima Kiran but future research needs to be focused on improving its yield potential for drought prone areas.

\section{Introduction}

Onion (Allium cepa L.), a member of Alliaceae family, is one of the important export oriented vegetable crop cultivated across the world. In India, it is the most popular and consumed spices in the daily human diet. In world, India ranks first in area and second in onion production (Kumar et al., 2015). India has about 1.2 million hectare area under onion cultivation constituting about
$10 \%$ of total acreage under vegetable with an annual production of 19.40MT in 2015 (Singh et al., 2017). From the last few years, area under onion cultivation is increasing due to its continuous demand in the national and international market. India itself supply onion to 38 different countries throughout the world in varying quantity. Thus, onion is not only important from food, nutritional and medicinal point of view but also provide an economic security to country. However the productivity 
of onion in India is about 16.13 tonnes/ha which is low in comparison to Republic of Korea where onion productivity was highest i.e. 57.03 tonnes/ha (Tripathi et al., 2017). This low productivity of onion might be due to the less genetic potential of short day onion varieties predominately grown in Indian subcontinent. Predicted climate change and global warming have resulted in the emergence of extreme weather events viz. erratic precipitation patterns leading to drought and floods, temperature extremes and soil salinity that act as the major constraint for agricultural productivity particularly the vegetable crops (Schmidt and Zinkernagel, 2017). Drought is one of the major abiotic stress that adversely influences growth and yield of economically important crops. Onion is a shallow rooted crop; with maximum roots in about $0.18 \mathrm{~m}$ top soil and only fewer roots penetrate deep in soil hence, irrigation water that moves below $0.76 \mathrm{~m}$ is not accessible to the onion crop (Drinkwater and Janes, 1955). This root morphology restricts the water availability from deeper soil zones, making the onion crop highly sensitive to water deficit stress especially when cultivated on coarse-textured soils (Rao, 2016). Additionally, drought stress disturbs many biochemical and physiological processes in crop plant that can be reflected by the phenotypic variations in response to stress. Plants have evolved several adaptive mechanisms to mitigate the effect of drought stress but the majority of strategies mostly involve the survival under stress. However from the crop production point of view any stress adaptive strategy must be associated with superior yield under a given stressful condition. Previous findings reported that water scarcity affects the onion bulb development drastically ultimately affecting its yield potential and quality (Pelter et al., 2004). But the limited information is available on the exact physiological and biochemical mechanism that get altered in response to drought stress in onion crop. The purpose of this study was to evaluate the effect of drought stress in popular onion variety Bhima Kiran on the basis of various morphological, physiological and biochemical traits that influences the overall bulb yield and quality in response to drought stress.

\section{Materials and Methods}

The study was carried out at ICAR-Directorate of onion and Garlic Research, Pune, Maharashtra, India $\left(18.32^{\circ}\right.$ North latitude and $73.51^{0}$ East longitude, $553.8 \mathrm{~m}$ above mean sea level, annual rainfall $574 \mathrm{~mm}$ ) in Rabi 2016. The experimental plot and soil type is suitable for onion production with $32-35 \%$ clay, $20 \%$ silt and $40 \%$ sand with soil $\mathrm{pH}$ of 7.9 and bulk density $1.4 \mathrm{Mgcm}^{-3}$. The experiment was laid out in randomized block design (RBD) with onion variety Bhima Kiran in three replications each consisting of about 400 seedlings in 6 sq. $\mathrm{m}$ plot size maintaining a spacing of $15 \times 10 \mathrm{~cm}$. All the necessary cultural practices like nursery, field preparation, fertigation, agronomic practices, plant protection measures and irrigation was carried out as per recommendation in order to raise the good crop. The treatment of drought stress was imposed on 45 days after transplanting for continuous 40 days by withholding irrigation after that normal irrigation schedule was practiced throughout the crop growth. The normal irrigation schedule was practiced in control plots throughout the crop growth phase.

\section{Water relations}

To monitor the soil water status, soil sample were randomly collected from the experimental plots at depth of 30 to $60 \mathrm{~cm}$ using an auger to determine the soil moisture level prior and after the stress treatment by using gravimetric meter method. Relative water content (RWC) which reflects the plant water status was calculated by using the 
formula given by Barrs and Weatherley (1962) method, where fresh weight of leaf were measured immediately after excision, thereafter immediately transferring leaf in petri-dishes containing distilled water for $4 \mathrm{~h}$ to record turgid weight $(\mathrm{g})$, followed by drying in hot air oven at $70^{\circ} \mathrm{C}$ till constant dry weight (g) has reached (72h).

RWC $(\%)=[($ Fresh wt. - Dry wt. $) /($ Turgid wt. - Dry wt.)] x 100

\section{Morphological parameters}

The growth and physiological response of plants were monitored 45 days after transplanting (DAT), 15 days (DAT), 30 days (DAT) and 40 days (DAT) after drought stress for various morphological observations. The phenotypic observations like plant height, number of leaves, leaf length, leaf area, pseudo-stem diameter and length were recorded from both control and stressed plants. For physiological and biochemical traits sampling $\left(4^{\text {th }}\right.$ leaf) was done during morphological observations from both irrigated and drought stress plots. Observations were recorded for all traits in replicates.

\section{Physiological and biochemical parameters}

Physiological and biochemical traits namely, chlorophyll, protein, lipid per-oxidation, proline, phenol, peroxidise and antioxidant activity was estimated from leaf sample whereas, biochemical traits like flavanoids, pyruvic acid and TSS were evaluated from bulb sample. Chlorophyll was estimated in $0.05 \mathrm{~g}(\mathrm{w})$ of leaf sample in $10 \mathrm{ml}(\mathrm{V})$ DMSO (dimethyl sulfoxide) by non-maceration method (Hiscox and Israelstam, 1979). Absorbance was recorded at 645 and $665 \mathrm{~nm}$ then total chlorophyll was calculated using formula of Arnon (1949). It is calculated as total chlorophyll $=\left(20.2 \times \mathrm{A}_{645}+8.02 \times \mathrm{A}_{663}\right)$ $x$ Volume of extract x Weight of sample/1000. Total soluble protein was estimated following the method of Lowry et al., (1951). Leaf damaged due to drought stress was evaluated by monitoring lipid per-oxidation level as given by Heath and Packer (1968). Proline was measured according to the method given by Bates et al., (1973). Phenol was measured by the method given by Bray et al., (1954). The antioxidant activity is determined by Ferric Reducing Antioxidant Power (FRAP) Assay method described by Benzie and Strain (1996. Pyruvic acid or pyruvate is an important metabolic in onion bulb directly correlated with its pungency was estimated as per given by Randle and Bussard (1993) whereas, total flavanoids was determined by method given by Olivera (2008). Total Soluble Solids (TSS) was measured from bulbs after harvest by using refractometer and expressed in ${ }^{0}$ Brix (Hanna instruments, USA).

\section{Yield traits}

Plants were harvested from irrigated and drought stressed plots when the leaves turned yellow and uniform neck fall occurred. The bulb size viz. polar bulb diameter and equatorial bulb diameter were measured using electronic digital calliper. Bulbs were separated from the plants and graded to determine the marketable bulb yield in $\mathrm{kg}$.

\section{Statistical analysis}

The results are expressed as means with standard error (S.E.). The ANOVA and significance critical difference (at $\mathrm{P}<0.05$ ) between control and stressed samples were determined by INDOSTAT and Microsoft Excel for all studied parameters.

\section{Results and Discussion}

Plant response to drought stress includes different morphological, physiological and 
metabolic changes. It can occur at any plant developmental stage however certain plant growth phase is highly sensitive for soil moisture status that severely hampers the overall crop yield (Toscano et al., 2016). Onion being a shallow rooted crop is highly sensitive to drought stress. With this background the present study were carried out with onion variety Bhima Kiran in order to evaluate the drought tolerance mechanisms through various morphological, physiological and biochemical analysis.

\section{Water relations}

Relative water content (RWC) act as a good indicator for plant water status that was significantly influenced by soil type and water status, irrigation schedule, crop variety and environmental constraints like drought stress. In the present study significant reduction in RWC was recorded in plant leaf tissue (70$73 \%$ ) as a consequence of drought stress in comparison to leaf (80-85\%) from irrigated plot. Soil water status was monitored by using soil gravimetric method. Prominent reductions in soil moisture were recorded under the influence of drought stress. Soil moisture content of $80-82 \%$ was recorded from normally irrigated plots whereas $65-70 \%$ moisture content found in drought affected plots. Both these parameters confirmed the effect of water deficit stress on plant and soil water status. It has been reported previously that drought stress diminishes plant water status (RWC) in several crops like in rice (Todaka et al., 2017) and tomato (Nir et al., 2014). The findings by Munne-Bosch et al., (2003) revealed that $80 \%$ RWC value indicated the good plant water status whereas, plant with 66-68\% RWC as moderately drought tolerant and RWC less that 50\% reflects plant under severe water deficit stress. Even though the reduction in RWC was recorded in onion variety Bhima Kiran under the influence of drought stress but still the plant was able to maintain its plant water potential and recovered after the stress treatment this showed that it has some adaptive traits and tolerance mechanism that protect the crop under stressful environment.

\section{Morphological traits}

The various morphological symptoms were easily observed after drought stress treatment however the appearance of symptoms varies among the different crop species. Morphological traits responsible for continuous and adaptive growth under drought stress were monitored weekly for continuous 40 days. In onion variety Bhima Kiran, significant reduction was not observed for the morphological traits recorded 2 weeks after drought stress it progresses only after 30 days of stress treatment. The growth trait like leaf length and leaf area decreases significantly in response to drought stress however, the other morphological parameters like number of leaves per plant, plant height, pseudo-stem length and diameter recorded non-significant differences from irrigated plot. This result revealed that onion variety Bhima Kiran can sustain water deficit stress for about 2 weeks with slight morphological changes but as the stress progresses the effect becomes severe day by day ultimately limiting the overall plant growth (Table 1). As the first response to water scarcity, the active plant cellular growth gets restricted so as to save the available water thereby reducing the leaf number and growth as one of the drought tolerance mechanism. The reduction in number of leaves and leaf area is also linked to the decrease in the leaf turgor potential as reported by Embiale et al., (2016) in Piscum sativum were drought stress adversely affected the overall plant growth, water status and leaf characteristics such as leaf number and area. In the present study the onion variety Bhima Kiran limits its leaf area and length in response to drought stress as one of the tolerance mechanism without affecting 
its other morphological traits that are directly linked with the yield performance of crop.

\section{Physiological and biochemical traits}

The best physiological approach for determining the drought tolerance ability of a particular variety is to monitor its stay-green trait mainly the chlorophyll content. Chlorophyll directly reflects the overall photosynthesis and assimilates formation that is linked with the overall crop growth and productivity. Non-significantly but higher chlorophyll content in leaf tissue of Onion cultivar Bhima Kiran reveals that it maintains it stay-green traits during drought stress which is the prerequisite parameter for drought tolerance. In potato, leaf chlorophyll content was used as an efficient indicator of tuber yield under drought condition (Ramirez et al., 2014). Recent findings in some vegetable crops like eggplant (Mibei et al., 2017) and raddish (Akram et al., 2016) further supports our finding where drought stress reduces the chlorophyll content however the tolerant cultivar maintains the higher chlorophyll and thereby the photosynthesis rate as one of the drought tolerance mechanism.

Table.1 Morphological parameters recorded in response to drought stress imposed 40 days after transplanting (DAT) viz., T1: Irrigated; T2: 15 days of drought stress (55 DAT); T3: 30 days of drought stress (70 DAT) ; T4: 40 days of drought stress (80 DAT) in onion variety

\begin{tabular}{|c|l|l|r|l|l|l|}
\hline $\begin{array}{c}\text { Drought } \\
\text { stress }\end{array}$ & $\begin{array}{l}\text { Leaf } \\
\text { length }\end{array}$ & $\begin{array}{l}\text { Leaf Area } \\
\text { cm }^{-2}\end{array}$ & $\begin{array}{l}\text { Leaves } \\
\text { Plant }^{-1}\end{array}$ & $\begin{array}{l}\text { Plant } \\
\text { height }\end{array}$ & $\begin{array}{l}\text { Pseudostem } \\
\text { length } \mathbf{( c m )}\end{array}$ & $\begin{array}{l}\text { Pseudostem } \\
\text { diameter }\end{array}$ \\
\hline & $\mathbf{( c m )}$ & & & $\mathbf{( c m )}$ & & $(\mathbf{m m})$ \\
\hline T1 & 44.6 & 19.3 & 7.5 & 44.4 & 17.0 & 11.3 \\
\hline T2 & 46.6 & 23.7 & 7.7 & 51.5 & 22.1 & 13.5 \\
\hline T3 & 47.0 & 23.5 & 7.7 & 53.5 & 19.3 & 13.4 \\
\hline T4 & 39.7 & 22.8 & 6.7 & 46.8 & 16.6 & 9.8 \\
\hline CD at 5\% & $\mathbf{3 . 5}$ & $\mathbf{1 . 9}$ & $\mathbf{1 . 1}$ & $\mathbf{3 . 4}$ & $\mathbf{1 . 2}$ & $\mathbf{1 . 9}$ \\
\hline
\end{tabular}

Table.2 Biochemical and yield associated parameters recorded in response to drought stress imposed 40 days after transplanting (DAT) in onion variety Bhima Kiran. Abbreviation; FW:

Fresh weight; DW: Dry weight

\begin{tabular}{|l|c|c|c|}
\hline Biochemical and yield traits & Irrigated & Drought & CD at 5\% \\
\hline Chlorophyll $(\mathrm{mg} / \mathrm{g} \mathrm{DW})$ & 0.28 & 0.25 & 0.09 \\
\hline Lipid peroxidation (TBARS content) & 43 & 53 & 4.30 \\
\hline Protein $(\mathrm{mg} / \mathrm{g}$ sample) & 11 & 8 & 1.33 \\
\hline Proline $(\mu \mathrm{mol} / \mathrm{g}$ FW) & 5 & 7 & 2.13 \\
\hline Antioxidant activity $(\mathrm{mg} / 100 \mathrm{~g} \mathrm{FW})$ & 243 & 236 & 4.12 \\
\hline Phenol $(\mathrm{mg} / 100 \mathrm{~g}$ Gallic acid) & 109 & 74 & 5.64 \\
\hline Flavanoids $(\mathrm{mg} / 100 \mathrm{~g}$ Quercitin) & 148 & 143 & 9.99 \\
\hline Pyruvic acid $(\mu \mathrm{mol} / \mathrm{g}$ FW) & 3.3 & 2.1 & 1.3 \\
\hline Total soluble solids $\left({ }^{0} \mathrm{Brix}\right)$ & 12 & 13 & 3.79 \\
\hline Bulb yield (ton/ha) & 47.6 & 16.6 & 8.2 \\
\hline Polar bulb size $(\mathrm{mm})$ & 54.7 & 45.4 & 4.33 \\
\hline Equator bulb size $(\mathrm{mm})$ & 43.0 & 31.2 & 11.9 \\
\hline Bhima Kiran. & & & \\
\hline
\end{tabular}


Drought stress induces the formation of detrimental reactive oxygen species (ROS) that directly damages the cellular membrane that affects the various cellular metabolic processes (Das and Roychoudhury, 2014). In plants, lipid peroxidation which is measured in terms of TBARS content gives an indication related to extent of cellular membrane damage due to lower cellular turgor and oxidative damage under drought stress (Blackman et al., 1995). Lower value of TBARS was associated with drought tolerance and act as one of the best physiological component for monitoring the drought stress (Sairam et al., 2000). In onion variety Bhima Kiran, water deficit stress significantly induces the cellular membrane damage as reflected by its TBAR contents (Table 2). On the other hand, plant maintains its osmotic potential in response to drought stress by accumulating various osmolytes like proline and thereby protects its cellular membrane (Ashraf and Foolad, 2007). Level of proline under drought stress has positive association with drought tolerant cultivar than in the sensitive one (Anjum et al., 2011). In our study significantly higher proline content was recorded in onion variety Bhima Kiran that might protect the cellular membrane and the various metabolic processes associated with it under water deficit condition (Table 2). A recent finding in cowpea by Zegaoui et al., (2017) supports the present result in onion crop under drought stress.

The plant subjected to drought stress become prone to oxidative damage that can be ease by inducing ROS scavenging antioxidant enzymes activity thereby alleviating the drought consequences (Foyer and Noctor, 2005). In several studies, under moderate drought stress the best adapted variety/cultivar exhibit increase in the antioxidant enzyme activity. In the present study, antioxidant enzyme activity was found to be significantly higher in the onion cultivar
Bhima Kiran in response to drought stress that further confirm its drought tolerance ability under moderate water deficit stress. This finding is further supported by the report in tomato (Sanchez-Rodriguez et al., 2016), finger millet (Bartwal et al., 2016) and other crops subjected to drought stress. Onions are economically important and widely consumed world-wide due to its significant health benefit. It contains a number of organo-sulfur and phenolic bioactive compounds, particularly polyphenols, flavanoids, pyruvic acid and total soluble solids that are responsible for its typical odour, flavour, nutritional benefit, pungency and storage life.

The bioaccumulation of these compounds depends on several factors but especially on the growing environment and variety (Liguori et al., 2017). Drought stress effects the crop physiology and biosynthesis of secondary metabolites like, phenols, flavanoids etc (Barbagallo et al., 2013). The present findings in onion cultivar Bhima Kiran report reduction in essential components namely the quality traits viz. phenols, flavanoids and pyruvic acid in response to drought stress however the decreases was not significant from both leaf and bulb tissues respectively (Table 2). The results were similar as those reported in tomato crop under drought stress (Nuruddin et al., 2003; Yin et al., 2010). Total soluble solids (TSS) were known as a beneficial indicator for the taste in onion. In the present study, drought stress slightly elevates the total soluble solids in onion bulbs in comparison to routinely irrigated plot (Table 2). Thus drought stress up to certain limit may benefit onion crop by enhancing the levels of its TSS that may improves the onion quality and flavour. The previous finding in tomato crop supports our results where drought stress induces the build-up of a large quantity of flavonoids and polyphenols in the adaptive tomato cultivar (Klunklin and Savage, 2017). Overall, the findings from the 
present study signify that the onion variety Bhima Kiran accumulate increase amount of organo-sulfur and phenolic compounds without changing any quality characteristics during drought stress.

\section{Yield and associated traits}

Onions are mainly cultivated as an irrigated crop in major part of India. Being a shallowrooted crop, timely and sufficient irrigation is essential to achieve good marketable size bulbs of more than $45 \mathrm{~mm}$ in diameter with profitable yield. However, any decrease in soil moisture content affects the overall crop growth performance and bulb yield. In our study significant variation in bulb yield was recorded from both irrigated and drought stress plot. The onion variety Bhima Kiran recorded $65 \%$ yield reduction when subjected to 40days of drought stress treatment with more number of ' $\mathrm{C}$ ' grade bulbs (Table 2). This is mainly due to significant reduction in both equatorial and polar bulb size. Previous findings are in agreement with our results where, water deficit stress induces early maturity in onion crop with small size partial or immature bulbs of poor marketable value that started early rooting in storage as compared to irrigated crop (Olalla et al., 2004; Pelter et al., 2004; Kumar et al., 2007; Kutty et al., 2014; Rop et al., 2016). Even though our study revealed that onion variety Bhima Kiran showed several adaptive mechanisms to cope with drought stress but the mechanisms which maintained its yield potential under such circumstance needs to be more focused in future.

\section{References}

Akram, N.A., Waseem, M., Ameen, R. and Ashraf, M., 2016. Trehalose pre-treatment induces drought tolerance in radish (Raphanus sativus L.) plants: some key physio-biochemical traits. Acta Physiologiae Plantarum., 38(1): p.3.
Anjum, S.A., Xie, X., Wang, L., Saleem, M.F., Man, C. and Lei, W., 2011. Morphological, physiological and biochemical responses of plants to drought stress. Afr. J. Agric. Res., 6: 2026-2032.

Arnon, D., 1949. Estimation of Total chlorophyll. Plant Physiol, 24(1): 1-15.

Ashraf, M. and Foolad, M.R., 2007. Roles of glycine betaine and proline in improving plant abiotic stress resistance. Environ. Exp. Bot., 59: 206-216.

Barbagallo, R.N., Isabella, D.S., Patane, C., 2013. Yield, physicochemical traits, antioxidant pattern, polyphenol oxidase activity and total visual quality of field-grown processing tomato $\mathrm{cv}$. Brigade as affected by water stress in Mediterranean climate. $J$. Agric. Food Chem., 93: 1449-1457.

Barrs, H.D. and Weatherley, P.E., 1962. A reexamination of the relative turgidity technique for estimating water deficits in leaves. Aust J Biol Sci., 15(3): 413-428.

Bartwal, A., Pande, A., Sharma, P. and Arora, S., 2016. Inter varietal variations in various oxidative stress markers and antioxidant potential of finger millet (Eleusine coracana) subjected to drought stress. $J$. Environ. Biol., 37(4): 517.

Bates L.S., Waldren R.P. and Tear, I.D., 1973. Rapid determination of free proline for water stresses studies. Plant Soil, 39: 205207.

Benzie, I.F. and Strain, J.J., 1996. The ferric reducing ability of plasma (FRAP) as a measure of "antioxidant power": the FRAP assay. Analytical biochemistry, 239(1): 70 76.

Blackman, S.A., Obendorf, R.L. and Leopold, A.C., 1995. Desiccation tolerance in developing soybean seeds: The role of stress proteins. Plant Physiol., 93: 630-638.

Castillo, F.I., Penel, I., Greppin, H. 1984. Peroxidase release induced by ozone in Sedum album leaves. Plant Physiol., 74: 846-851.

Das, K. and Roychoudhury, A., 2014. Reactive oxygen species (ROS) and response of antioxidants as ROS-scavengers during environmental stress in plants. Front Environ Sci., 2: 53.

De Santa Olalla, F.M., Dominguez-Padilla, A. and 
Lopez, R., 2004. Production and quality of the onion crop (Allium cepa L.) cultivated under controlled deficit irrigation conditions in a semi-arid climate. Agric Water Manag, 68(1): 77-89.

Drinkwater, W.O. and B.E. Janes, 1955. Effects of irrigation and soil moisture on maturity, yield and storage of two onion hybrids. Proc. Amer. Soc. Hort. Sci., 66: 267- 279.

Embiale, A., Hussein, M., Husen, A., Sahile, S. and Mohammed, K., 2016. Differential sensitivity of Pisum sativum L. cultivars to water-deficit stress: changes in growth, water status, chlorophyll fluorescence and gas exchange attributes. J Agron, 15(2): 45.

Foyer, C.H. and Noctor, G., 2005. Oxidant and antioxidant signalling in plants: a re- evaluation of the concept of oxidative stress in a physiological context. Plant, Cell \& Environment., 28(8): 1056-1071.

Heath, R.L. and Packer, L., 1968. Photoperoxidation in isolated chloroplasts: I. Kinetics and stoichiometry of fatty acid peroxidation. Arch. Biochem. Biophys, 125(1): 189-198.

Hiscox, J.T. and Israelstam, G.F., 1979. A method for the extraction of chlorophyll from leaf tissue without maceration. Can $J$ Bot., 57(12): 1332-1334.

Klunklin, W. and Savage, G., 2017. Effect on Quality Characteristics of Tomatoes Grown Under Well-Watered and Drought Stress Conditions. Foods, 6(8): 56.

Kumar, S., Imtiyaz, M., Kumar, A. and Singh, R., 2007. Response of onion (Allium cepa L.) to different levels of irrigation water. Agric Water Manag, 89(1): 161-166.

Kumar, V., Neeraj, S.S. and Sagar, N.A., 2015. Post-harvest management of fungal diseases in onion-a review. Int. J. Curr. Microbiol. App. Sci, 4(6): 737-752.

Kutty, M.S., Gowda, R.V. and Rao, N.K.S., 2014. Genotypic variability for physiological, biochemical and morphological responses to drought stress in onion (Allium cepa L.). Trop. Agric., 41(3216): 040202-18.

Liguori, L., Califano, R., Albanese, D., Raimo, F., Crescitelli, A. and Di Matteo, M., 2017. Chemical Composition and Antioxidant Properties of Five White Onion (Allium cepa L.) Landraces. J. Food Qual., 2017.
Lowry, O.H., Rosebrough, N.J., Farr, A.L. and Randall, R.J., 1951. Protein measurement with the Folin phenol reagent. Journal of biological chemistry, 193(1): 265-275.

Mibei, E.K., Ambuko, J., Giovannoni, J.J., Onyango, A.N. and Owino, W.O., 2017. Carotenoid profiling of the leaves of selected African eggplant accessions subjected to drought stress. Food Sci. Nutr., 5(1): 113-122.

Munne-Bosch, S., Jubany-Mari, T. and Alegre, L., 2003. Enhanced photo- and anti-oxidative protection, and hydrogen peroxide accumulation in drought-stressed Cistusclusii and Cistusalbidus plants. Tree Physiol., 23: 1-12.

Nir, I., Moshelion, M. and Weiss, D., 2014. The Arabidopsis gibberellin methyl transferase 1 suppresses gibberellins activity, reduces whole plant transpiration and promotes drought tolerance in transgenic tomato. Plant Cell Environ, 37(1): 113-123.

Nuruddin, M.M., Madramootoo, C.A., Dodds, G.T., 2003. Effects of water stress at different growth stages on greenhouse tomato yield and quality. Hort Science, 38: 1389- 1393.

Oliveira, I., Sousa, A., Ferreira, I. C., Bento, A., Estevinho, L., Pereira, J. A., 2008. Total phenols, antioxidant potential and antimicrobial activity of walnut (Juglans regia L.) green husks, Food Chemi Toxicol., 46(7): 2326-2331.

Pelter, G.Q., Mittelstadt, R., Leib, B.G. and Redulla, C.A., 2004. Effects of water stress at specific growth stages on onion bulb yield and quality. Agric Water Manag, 68(2): 107- 115.

Ramirez, D.A., Yactayo, W., Gutierrez, R., Mares, V., De Mendiburu, F., Posadas, A. and Quiroz, R., 2014. Chlorophyll concentration in leaves is an indicator of potato tuber yield in water-shortage conditions. Sci Hort., 168: 202-209.

Randle W M and Bussard M L. 1993. Streamlining onion pungency analysis. HortScience 28:60.

Rop, D.K., Kipkorir, E.C. and Taragon, J.K., 2016. Effects of Deficit Irrigation on Yield and Quality of Onion Crop. J Agric Sci., 8(3): 112. 
Sairam, R.K., Srivastava, G.C., and Saxena, D.C., 2000. Increased antioxidant activity under elevated temperatures: a mechanism of heat stress tolerance in wheat genotypes. Biol. Plant., 43: 245-251.

Sanchez-Rodriguez, E., Romero, L. and Ruiz, J.M., 2016. Accumulation of free polyamines enhances the antioxidant response in fruits of grafted tomato plants under water stress. J. Plant Physiol., 190: 72-78.

Schmidt, N. and Zinkernagel, J., 2017. Model and Growth Stage Based Variability of the Irrigation Demand of Onion Crops with Predicted Climate Change. Water, 9(9): 693.

Singh, M.K., Srivastava, N. and Singh, R.K., 2017. Integrated effect of bio fertilizers and inorganic fertilizers on growth, yield and quality of onion (Allium cepa L.). $J$ Pharmacogn Phytochem., 6(5): 841-1844.

Todaka, D., Zhao, Y., Yoshida, T., Kudo, M., Kidokoro, S., Mizoi, J., Kodaira, K.S., Takebayashi, Y., Kojima, M., Sakakibara, H. and Toyooka, K., 2017. Temporal and spatial changes in gene expression, metabolite accumulation and phytohormone content in rice seedlings grown under drought stress conditions. Plant J., 90(1): 61-78.

Toscano, S., Farieri, E., Ferrante, A. and Romano, D., 2016. Physiological and Biochemical Responses in Two Ornamental Shrubs to Drought Stress. Front Plant Sci., 7: 645645.

Tripathi, P.C., Sankar, V. and Lawande, K.E., 2017. Micro irrigation in onion (Allium сера) and garlic (A. sativum)-a review. Current Horticulture, 5(1): 3-14.

Yin, Y.G., Kobayashi, Y., Sanuki, A., Kondo, S., Fukuda, N., Ezura, H., Sugaya, S., Matsukura, C., 2010. Salinity induces carbohydrate accumulation and sugarregulated starch biosynthetic genes in tomato (Solanum lycopersicum L. cv. 'Micro-Tom') fruits in an ABA- and osmotic stress-independent manner. J. Exp. Bot., 61: 563-574.

Zegaoui, Z., Planchais, S., Cabassa, C., Djebbar, R., Belbachir, O.A. and Carol, P., 2017. Variation in relative water content, proline accumulation and stress gene expression in two cowpea landraces under drought. $J$ Plant Physiol., 218: 26-34.

\section{How to cite this article:}

Ghodke, P.H., P.S. Andhale, U.M. Gijare, A. Thangasamy, Y.P. Khade, V. Mahajan and Singh, M. 2018. Physiological and Biochemical Responses in Onion Crop to Drought Stress. Int.J.Curr.Microbiol.App.Sci. 7(01): 2054-2062. doi: https://doi.org/10.20546/ijcmas.2018.701.247 